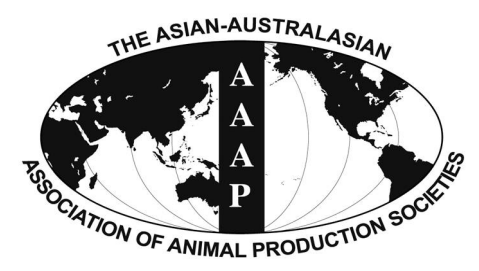

Open Access

Asian Australas. J. Anim. Sci.

Vol. 29, No. 11 : 1639-1645 November 2016

http://dx.doi.org/10.5713/ajas.15.1053

www.ajas.info

pISSN 1011-2367 elSSN 1976-5517

\title{
Marination and Physicochemical Characteristics of Vacuum-aged Duck Breast Meat
}

\author{
Muhammad Issa Khan ${ }^{1,2}$, Hyun Jung Lee ${ }^{1}$, Hyun-Joo Kim³, \\ Hae In Young ${ }^{1}$, Haelim Lee ${ }^{1}$, and Cheorun Jo ${ }^{1, *}$ \\ ${ }^{1}$ Department of Agricultural Biotechnology, Center for Food and Bioconvergence, \\ Research Institute of Agriculture and Life Science, Seoul National University, Seoul 08826, Korea
}

\begin{abstract}
We investigated marinade absorption and physicochemical characteristics of vacuum-aged duck breasts that were halved and individually vacuum-packed for chiller aging at $4{ }^{\circ} \mathrm{C}$ for $14 \mathrm{~d}$. One half was marinated for 0,7 , or $14 \mathrm{~d}$, while the second half was used as a control. Marinade absorption, cooking loss, cooking yield, texture profile, $\mathrm{pH}$, color, protein solubility, and thiobarbituric acid reactive substances (TBARS) values were evaluated, and protein sodium dodecyl sulfate-polyacrylamide gel electrophoresis (SDSPAGE) was performed. Marinade absorption and $\mathrm{pH}$ did not vary significantly after $14 \mathrm{~d}$ of aging. Marination increased the $\mathrm{pH}$, color $\left(\mathrm{a}^{*}\right.$ and $\mathrm{b}^{*}$ ) values, and cooking yield and reduced cooking loss. TBARS values significantly increased with aging time, but were significantly reduced by marination. Myofibril and total protein solubility increased with aging and marination, while SDS-PAGE showed protein degradation. Hence, aging and marination can be used simultaneously to improve physicochemical quality and cooking yield of vacuum-aged duck breast. (Key Words: Aging, Marination, Duck Breast, Protein Solubility)
\end{abstract}

\section{INTRODUCTION}

Meat tenderness and juiciness are important criteria for consumers in the assessment of meat quality (Piao et al., 2015), and several postmortem operations have been recently considered to improve meat tenderness. Marination has been used to improve the tenderness, juiciness, flavor, color, and cooking yield of meat and poultry (GuerreroLegarreta and Hui, 2010). Alvarado and Sams (2004) reported an improvement in chicken breast tenderness by marination treatment, while reduced cooking and drip losses were observed by Yoon (2002) for chicken breast marinated with trisodium phosphate or sodium tripolyphosphate.

The functionality of marinades directly depends upon

\footnotetext{
* Corresponding Author: Cheorun Jo. Tel: +82-2-880-4804, Fax:+82-2-873-2271, E-mail: cheorun@snu.ac.kr

${ }^{2}$ National Institute of Food Science and Technology, University of Agriculture, Faisalabad 38040, Pakistan.

${ }^{3}$ Crop Post-harvest Technology Division, National Institute of Crop Science, RDA, Suwon 16613, Korea.

Submitted Dec. 23, 2015; Revised Feb. 9, 2016; Accepted Feb. 29, 2016
}

their ingredients. Salt and phosphate are common ingredients in most alkaline marinades (Lemos et al., 1999). Salt enhances meat flavor, extracts salt-soluble proteins in conjunction with phosphate, increases marinade absorption, and increases moisture retention during storage and further processing (Smith and Acton, 2010). Phosphate improves water-holding capacity by increasing the meat $\mathrm{pH}$ and unfolding muscle proteins (Yoon, 2002). A marinade can be acidic or alkaline in nature (Smith and Acton, 2010), and meat tenderization is achieved by marination, which leads to puffiness in muscle fiber owing to an increase in $\mathrm{pH}$, acceleration of the weakening of muscle structure, and enhancement of collagen solubilization by cooking (Wahlgren et al., 1997). There are several methods for the practical application of meat marination including injection, immersion, tumbling, or their combination (Bauermeister and McKee, 2005).

Duck meat and meat products are popular in Southeast Asia, but are perceived to be tough by consumers (Smith et al., 1993). Compared to chicken breast, duck breast meat has a higher amount of red muscle fibers (Smith et al., 
1993) and is regarded as red meat. The biochemical changes occurring postmortem play an important role in determining the ultimate quality and palatability of meat. It is generally accepted that the postmortem proteolysis of cytoskeletal proteins improves meat tenderness and $\mu$-calpain plays an essential role in postmortem proteolysis (Camou et al., 2007). Zhuang and Savage (2012) observed an increased water-holding capacity in chicken breast aged for $7 \mathrm{~d}$ compared to that in chicken breast aged for $2 \mathrm{~h}$. Lin et al. (2000) revealed that marination of duck meat with red wine induced significant postmortem changes and improved flavor profile and yield of the finished product. Keeping in view the nature of duck breast meat and the advantages of postmortem aging and marination treatment, the present study was designed to assess marinade absorption and physicochemical characteristics of vacuum-aged duck breast meat.

\section{MATERIALS AND METHODS}

\section{Procurement of raw material}

Duck (Cherry Valley) meat was procured from a commercial processing plant and transported to the laboratory in iceboxes. The breast portion of ducks was separated and marination treatments were applied according to the study plan. One sample was taken as control (without marination) for comparison. Each piece was vacuumpacked separately for postmortem aging of $14 \mathrm{~d}$ at $4{ }^{\circ} \mathrm{C}$ and was analyzed for marinade absorption and physicochemical characteristics at regular intervals $(1,7$, and $14 \mathrm{~d})$.

\section{Preparation of marinade and marination}

The marinade was formulated using $3 \% \mathrm{NaCl}$ and $1.5 \%$ sodium tripolyphosphate to have an acceptable $\mathrm{NaCl}$ and phosphate concentration in the finished product. The marinade was prepared one day before application and was stored at $4^{\circ} \mathrm{C}$. Marination was performed using a combination of manual injection and immersion processes. Pre-weighed breast fillets were injected with approximately $10 \%$ (on a weight basis) of refrigerated marinade and were immersed in excess marinade for $4 \mathrm{~h}$ at $4^{\circ} \mathrm{C}$. The breast fillets were allowed to drain off excess marinade after $4 \mathrm{~h}$ and were weighed to determine marinade absorption using the given equation:

$$
\begin{aligned}
& \text { Marinade absorption }(\%) \\
& =100 \times\left(\mathrm{Wt}_{\text {marinated }}-\mathrm{Wt}_{\text {raw }}\right) / \mathrm{Wt}_{\text {raw }}
\end{aligned}
$$

Where, $\mathrm{Wt}_{\text {raw }}$ and $\mathrm{Wt}_{\text {marinated }}$ are the weight of fillet before and after margination, respectively.

pH values and Commission Internationale de l'Eclairage

\section{color}

The $\mathrm{pH}$ value was measured using a $\mathrm{pH}$ meter (SevenGo, Mettler-Toledo Inc., Greifensee, Zürich, Switzerland). The duck breast sample ( 1 g) was homogenized with $9 \mathrm{~mL}$ of distilled water by using tissue homogenizer for $30 \mathrm{~s}$, centrifuged at $2,665 \mathrm{~g}$ for $10 \mathrm{~min}$, and filtered. The $\mathrm{pH}$ was measured by immersion of an electrode in the filtered samples. The surface color (Commission Internationale de l'Eclairage [CIE] $\mathrm{L}^{*}, \mathrm{a}^{*}$, and $b^{*}$ ) of marinated and unmarinated duck breast was measured using a colorimeter (CR-310, Minolta Co., Ltd., Osaka, Japan), and three observation readings were taken for each measurement.

\section{Cooking loss and cooking yield}

Marinated and unmarinated samples in bags were cooked in a water bath at $80^{\circ} \mathrm{C}$ for $30 \mathrm{~min}$ to achieve a core temperature of $70^{\circ} \mathrm{C}$. The samples were cooled to room temperature, surface dried, and weighed to assess the cooking loss. Cooking loss was determined as per the equation given below.

$$
\begin{aligned}
& \text { Cooking loss }(\%) \\
& =100 \times\left(\mathrm{Wt}_{\text {pre-cooked }}-\mathrm{Wt}_{\text {cooked }}\right) / \mathrm{Wt}_{\text {pre-cooked }}
\end{aligned}
$$

\section{2-Thiobarbituric acid reactive substances assay}

Lipid oxidation was determined by measuring thiobarbituric acid reactive substances (TBARS) values according to the method described by Lee et al. (2015). Marinated, unmarinated, and cooked samples (5 g) were added to $15 \mathrm{~mL}$ of distilled water and $50 \mu \mathrm{L}$ butylated hydroxytoluene $(7.2 \%$ in ethanol) in a centrifuge tube (50 $\mathrm{mL}$ ) and were homogenized using tissue homogenizer for $30 \mathrm{~s}$. The homogenate $(1 \mathrm{~mL})$ was transferred to another centrifuge tube $(15 \mathrm{~mL})$ and $2 \mathrm{~mL}$ of a thiobarbituric acid (TBA)/trichloroacetic acid (TCA) solution (20 mM TBA in $15 \%$ TCA) was added. Tubes were heated in a water bath at $90^{\circ} \mathrm{C}$ for $30 \mathrm{~min}$, cooled in iced water, and centrifuged at $2,665 \mathrm{~g}$ for $10 \mathrm{~min}$. The absorbance of the supernatant was measured at $532 \mathrm{~nm}$ using a spectrophotometer (DU 530, Beckman Instruments Inc., Fullerton, CA, USA) and the mg malondialdehyde $/ \mathrm{kg}$ sample was calculated.

\section{Protein solubility}

Total and sarcoplasmic protein solubility was measured according to the method described by Joo et al. (1999). Myofibril protein solubility was calculated by the difference between these measurements (total protein solubility sarcoplasmic protein solubility). Sarcoplasmic proteins were extracted from 2-g samples using $20 \mathrm{~mL}$ of iced and cooled $0.025 \mathrm{M}$ potassium phosphate buffer ( $\mathrm{pH}$ 7.2), and total proteins were extracted from 1-g samples using $20 \mathrm{~mL}$ 
of iced and cooled $1.1 \mathrm{M}$ potassium iodide in $0.1 \mathrm{M}$ phosphate buffer ( $\mathrm{pH}$ 7.2). Minced samples were homogenized with their respective buffer and were shaken at $4^{\circ} \mathrm{C}$ overnight. Samples were centrifuged at $566 \mathrm{~g}$ for 20 $\mathrm{min}$, and the protein concentration in the supernatant was measured by the Biuret method by using bovine serum albumin as a standard.

\section{Sodium dodecyl sulfate polyacrylamide gel electrophoresis of sarcoplasmic and myofibril proteins}

Sarcoplasmic and myofibril proteins for sodium dodecyl sulfate polyacrylamide gel electrophoresis (SDS-PAGE) were extracted by the method described by Lorenzo et al. (2013), with slight modifications. Marinated and unmarinated aged duck breast meat samples (4 g) were homogenized with $0.03 \mathrm{M}$ phosphate buffer ( $\mathrm{pH}$ 7.4) using tissue homogenizer for $30 \mathrm{~s}$. The homogenate was centrifuged at $10,000 \mathrm{~g}$ for $20 \mathrm{~min}$ at $4^{\circ} \mathrm{C}$, and the supernatant was separated as sarcoplasmic proteins. The resultant pellet was used for myofibril extraction; it was dissolved in $40 \mathrm{~mL}$ of $0.01 \mathrm{~N}$ phosphate buffer $(\mathrm{pH} 6.5)$ and centrifuged at $10,000 \mathrm{~g}$ for $20 \mathrm{~min}$ at $4^{\circ} \mathrm{C}$. The supernatant was discarded and the pellet was washed three times with $0.01 \mathrm{~N}$ phosphate buffer and dissolved in $0.03 \mathrm{~N}$ phosphate buffer (pH 6.5) containing $0.7 \mathrm{M} \mathrm{KI}$ and $0.02 \% \mathrm{NaN}_{3}$ with a liquid/solid ratio of 9 . Both protein fractions were filtered through $0.45-\mu \mathrm{m}$ filter paper, and the protein concentration was set at $1 \mathrm{mg} / \mathrm{mL}$ by Biuret method for protein determination. SDS-PAGE was performed by the following method described by Laemmli (1970), using separation gel $(7.5 \%)$ and stacking gel (4\%). Samples $(1 \mathrm{mg}$ protein $/ \mathrm{mL}$, $10 \mu \mathrm{L}$ ) were mixed with $19 \mu \mathrm{L}$ of Laemmli buffer and $1 \mu \mathrm{L}$ of mercaptoethanol. Samples $(20 \mu \mathrm{L})$ and protein molecular weight standards (25 to $250 \mathrm{kDa}$ ) were loaded onto gel and electrophoresis was performed in the AE-6531 mPAGE system (ATTO Corporation, Tokyo, Japan) and conducted at $220 \mathrm{~V}$ for $150 \mathrm{~min}$. Gels were stained with Coomassie brilliant blue R-250 and were scanned after detaining. The proteins were identified according to their molecular weights estimated by their relative motilities compared to the molecular weight standards.

\section{Texture profile analysis}

Texture profile analysis (TPA) of marinated and unmarinated, cooked samples was carried out using a texture analyzer (TA1 Lloyd Material Testing, West Sussex, UK). Cooked samples were cut into pieces of $1 \times 1 \times 2 \mathrm{~cm}$ (width $\times$ length $\times$ height) and were compressed to $60 \%$ with $50 \mathrm{~mm}$ probe having trigger load $5 \mathrm{~g}$ to measure hardness, cohesiveness, springiness, gumminess, and chewiness.

\section{Statistical analysis}

Statistical analysis was performed using the analysis of
Table 1. Effect of aging on marination absorption (\%) of duck breast

\begin{tabular}{lcccc}
\hline & \multicolumn{3}{c}{ Aging period (d) } & \multirow{2}{*}{ SEM } \\
\cline { 2 - 4 } & 1 & 7 & 14 & \\
\hline Absorption (\%) & 18.74 & 16.73 & 18.59 & 0.678 \\
\hline
\end{tabular}

SEM, standard error of the means $(\mathrm{n}=9)$.

variance to estimate the effect of aging on the marinade absorption and physicochemical characteristics of duck breast meat, and significant differences between the mean values were identified with Tukey's multiple range test, using SAS software, at a confidence level of $\mathrm{p}<0.05$ (SAS 9.3, SAS Institute Inc., Cary, NC, USA).

\section{RESULTS}

Postmortem aging showed non-significant impact on the marinade absorption of duck breast, as shown in Table 1. Marinade absorption varied from $16.73 \%$ to $18.74 \%$, and the lowest absorption (16.73\%) was observed for duck breast fillets having higher $\mathrm{pH}$ values (6.24). The CIE color $a^{*}$ and $b^{*}$ values showed significant variations because of postmortem aging, while the $L^{*}$ value was unchanged (Table 3). However, marination of postmortem aged duck breast did not show a consistent impact on CIE color values. Additionally, postmortem aging had non-significant impact on the cooking loss and cooking yield of duck breast meat (Table 4). However, marination significantly reduced the cooking loss and improved cooking yield compared to control, as indicated in Table 4. The lowest cooking loss was observed in duck breast meat marinated after $14 \mathrm{~d}$ of aging, while unmarinated samples showed maximum loss on day 14 of aging. Similar results were observed for cooking yield, as the highest yield was observed for samples marinated after $14 \mathrm{~d}$ of aging.

The results explicated in Table 5 indicate that aging results in an increased production of TBARS, and the marination of duck breast meat significantly reduced the TBARS value on respective aging days. The TBARS value of cooked samples showed a minimum increase for marinated samples, while a many-fold increase was observed for unmarinated samples. Myofibril and total

Table 2. Effect of aging and marination on $\mathrm{pH}$ of duck breast meat

\begin{tabular}{lcccc}
\hline \multirow{2}{*}{ Treatments } & \multicolumn{3}{c}{ Aging period (d) } & \multirow{2}{*}{ SEM $^{1}$} \\
\cline { 2 - 4 } & 1 & 7 & 14 & \\
\hline Control & $6.05^{\mathrm{b}}$ & $6.24^{\mathrm{b}}$ & $6.18^{\mathrm{b}}$ & 0.062 \\
Marinated & $6.55^{\mathrm{a}}$ & $6.61^{\mathrm{a}}$ & $6.60^{\mathrm{a}}$ & 0.049 \\
SEM $^{2}$ & 0.054 & 0.064 & 0.049 & - \\
\hline
\end{tabular}

SEM, standard error of the means.

${ }^{1} \mathrm{n}=9 .{ }^{2} \mathrm{n}=6$.

${ }^{a-c}$ Different letters within the same column differ significantly ( $\left.<<0.05\right)$.

${ }^{A-C}$ Different letters within the same row differ significantly $(p<0.05)$. 
Table 3. Effect of aging and marination on color of duck breast meat

\begin{tabular}{llcccc}
\hline & Treatments & \multicolumn{4}{c}{ Aging period (d) } \\
\cline { 3 - 5 } & & 1 & 7 & SEM $^{1}$ \\
\hline CIE L* $^{*}$ & Control & 49.64 & 43.93 & 47.85 & 2.202 \\
& Marinated & 48.59 & 44.61 & 49.55 & 1.884 \\
& SEM $^{2}$ & 2.994 & 0.800 & 1.728 & - \\
$\mathrm{CIE} \mathrm{a}^{*}$ & Control & $13.45^{\mathrm{aB}}$ & $14.53^{\mathrm{A}}$ & $15.32^{\mathrm{A}}$ & 0.291 \\
& Marinated & $12.61^{\mathrm{bB}}$ & $14.05^{\mathrm{AB}}$ & $14.42^{\mathrm{A}}$ & 0.423 \\
& SEM $^{2}$ & 0.202 & 0.470 & 0.367 & \\
$\mathrm{CIE} \mathrm{b}^{*}$ & Control & $-0.62^{\mathrm{B}}$ & $-0.23^{\mathrm{bAB}}$ & $1.61^{\mathrm{A}}$ & 0.559 \\
& Marinated & $-0.37^{\mathrm{B}}$ & $0.87^{\mathrm{aB}}$ & $3.44^{\mathrm{A}}$ & 0.592 \\
& SEM $^{2}$ & 0.749 & 0.171 & 0.636 & - \\
\hline
\end{tabular}

SEM, standard error of the means; CIE, Commission Internationale de l'Eclairage.

${ }^{1} \mathrm{n}=9 .{ }^{2} \mathrm{n}=6$.

${ }^{a-c}$ Different letters within the same column differ significantly $(\mathrm{p}<0.05)$.

${ }^{A-C}$ Different letters within the same row differ significantly $(\mathrm{p}<0.05)$.

protein solubility increased significantly with respect to aging time and marination, while no change in sarcoplasmic protein solubility was observed (Table 6 ).

The SDS-PAGE profiles of sarcoplasmic and myofibril proteins are depicted in Figure 1 which shows the effects of the aging and marination process. High molecular weight $(150 \mathrm{kDa}, 80 \mathrm{kDa}$, and $55 \mathrm{kDa})$ sarcoplasmic proteins showed dissociation and the appearance of new protein bands, while accumulation was shown for low molecular weight sarcoplasmic proteins (25 to $40 \mathrm{kDa}$ ). Both aging and marination had an impact on sarcoplasmic protein dissociation, as shown in Figure 1A. Marinated samples showed a lower density of protein on their respective bands, indicating its impact on protein degradation. Low molecular weight myofibril proteins appeared mainly in the range of 25 to $40 \mathrm{kDa}$, as shown in Figure 1B.

The texture profile analysis of duck breast meat showed no significant differences, both as a function of aging and marination, as shown in Table 7. However, marinated duck breast meat showed a slight reduction in all parameters of the texture profile compared to unmarinated samples,

Table 4. Effect of aging and marination on cooking loss and yield of duck breast meat

\begin{tabular}{|c|c|c|c|c|c|}
\hline & \multirow{2}{*}{ Treatments } & \multicolumn{3}{|c|}{ Aging period (d) } & \multirow{2}{*}{$\mathrm{SEM}^{1}$} \\
\hline & & 1 & 7 & 14 & \\
\hline \multirow{3}{*}{$\begin{array}{l}\text { Cooking loss } \\
(\%)\end{array}$} & Control & $32.21^{\mathrm{a}}$ & $32.29^{\mathrm{a}}$ & $33.29^{\mathrm{a}}$ & 1.248 \\
\hline & Marinated & $23.71^{\mathrm{bAB}}$ & $26.27^{\mathrm{bA}}$ & $20.57^{\mathrm{bB}}$ & 1.216 \\
\hline & SEM $^{2}$ & 0.505 & 1.952 & 0.698 & - \\
\hline \multirow{3}{*}{$\begin{array}{l}\text { Cooking yield } \\
(\%)\end{array}$} & Control & $67.79^{\mathrm{b}}$ & $67.70^{\mathrm{b}}$ & $66.71^{\mathrm{b}}$ & 1.248 \\
\hline & Marinated & $93.89^{\mathrm{aA}}$ & $88.50^{\mathrm{aB}}$ & $96.15^{\mathrm{aA}}$ & 1.232 \\
\hline & $\mathrm{SEM}^{2}$ & 0.851 & 1.766 & 0.878 & - \\
\hline
\end{tabular}

SEM, standard error of the means.

${ }^{1} \mathrm{n}=9 .{ }^{2} \mathrm{n}=6$

${ }^{a-c}$ Different letters within the same column differ significantly $(p<0.05)$.

${ }^{\text {A-C }}$ Different letters within the same row differ significantly $(p<0.05)$.
Table 5. Effect of aging and marination on lipid oxidation of duck breast meat

\begin{tabular}{|c|c|c|c|c|c|}
\hline \multirow{2}{*}{ State } & \multirow{2}{*}{ Treatments } & \multicolumn{3}{|c|}{ Aging period (d) } & \multirow{2}{*}{$\mathrm{SEM}^{1}$} \\
\hline & & 1 & 7 & 14 & \\
\hline \multirow[t]{3}{*}{ Raw } & Control & $0.45^{\mathrm{aC}}$ & $0.52^{\mathrm{aB}}$ & $0.71^{\mathrm{aA}}$ & 0.011 \\
\hline & Marinated & $0.38^{\mathrm{bB}}$ & $0.46^{\mathrm{bAB}}$ & $0.50^{\mathrm{bA}}$ & 0.031 \\
\hline & $\mathrm{SEM}^{2}$ & 0.026 & 0.008 & 0.031 & - \\
\hline \multirow[t]{3}{*}{ Cooked } & Control & $2.26^{\mathrm{a}}$ & $2.34^{\mathrm{a}}$ & $2.56^{\mathrm{a}}$ & 0.155 \\
\hline & Marinated & $0.46^{\mathrm{b}}$ & $0.59^{\mathrm{b}}$ & $0.59^{\mathrm{b}}$ & 0.053 \\
\hline & $\mathrm{SEM}^{2}$ & 0.097 & 0.057 & 0.166 & - \\
\hline
\end{tabular}

SEM, standard error of the means.

${ }^{1} \mathrm{n}=9 .{ }^{2} \mathrm{n}=6$.

${ }^{\mathrm{a}-\mathrm{c}}$ Different letters within the same column differ significantly $(\mathrm{p}<0.05)$.

${ }^{A-C}$ Different letters within the same row differ significantly $(\mathrm{p}<0.05)$.

especially for shear force (data not shown).

\section{DISCUSSION}

Postmortem changes in meat play a vital role in determining the quality of meat. The information regarding the nutritional value, physicochemical attributes and postmortem changes in the duck meat is of prime importance for meat processing industries to consider the use of duck meat for manufacturing different meat-based products (Huda et al., 2011). Zhuang et al. (2014) assessed the effects of postmortem aging on the marination performance of broiler breast and observed that aging prior to marination did not affect marinade absorption. Sodium chloride and phosphate-based marination is categorized as an alkaline marinade resulting in a significant increase in duck breast pH (Table 2). Sen et al. (2005) studied the impact of chilling, phosphate, and bicarbonate marination on broiler breast meat quality and observed an increase in $\mathrm{pH}$ of broiler breast after marination. The marination of duck breast results in an increase in meat $\mathrm{pH}$, and the elevated $\mathrm{pH}$ is associated with an increased water-holding

Table 6. Effect of aging and marination on protein solubility of duck breast meat

\begin{tabular}{|c|c|c|c|c|c|}
\hline & \multirow{2}{*}{ Treatments } & \multicolumn{3}{|c|}{ Aging period (d) } & \multirow{2}{*}{ SEM $^{1}$} \\
\hline & & 1 & 7 & 14 & \\
\hline \multirow[t]{3}{*}{ Sarcoplasmic } & Control & 3.74 & 3.88 & 3.85 & 0.333 \\
\hline & Marinated & 4.18 & 4.37 & 3.95 & 0.261 \\
\hline & $\mathrm{SEM}^{2}$ & 0.478 & 0.182 & 0.855 & - \\
\hline \multirow[t]{3}{*}{ Myofibril } & Control & $4.93^{\mathrm{bB}}$ & $8.55^{\mathrm{bA}}$ & $8.57^{\mathrm{bA}}$ & 0.533 \\
\hline & Marinated & $6.01^{\mathrm{aB}}$ & $8.95^{\mathrm{aA}}$ & $9.38^{\mathrm{aA}}$ & 0.294 \\
\hline & $\mathrm{SEM}^{2}$ & 0.361 & 0.160 & 0.268 & - \\
\hline \multirow[t]{3}{*}{ Total } & Control & $8.67^{\mathrm{bB}}$ & $11.65^{\mathrm{bA}}$ & $12.43^{\mathrm{bA}}$ & 0.506 \\
\hline & Marinated & $10.19^{\mathrm{aB}}$ & $12.97^{\mathrm{aA}}$ & $13.32^{\mathrm{aA}}$ & 0.529 \\
\hline & $\mathrm{SEM}^{2}$ & 0.550 & 0.167 & 0.306 & - \\
\hline
\end{tabular}

SEM, standard error of the means.

${ }^{1} \mathrm{n}=9 .{ }^{2} \mathrm{n}=6$.

${ }^{a-c}$ Different letters within the same column differ significantly ( $\left.p<0.05\right)$.

${ }^{A-C}$ Different letters within the same row differ significantly $(\mathrm{p}<0.05)$. 

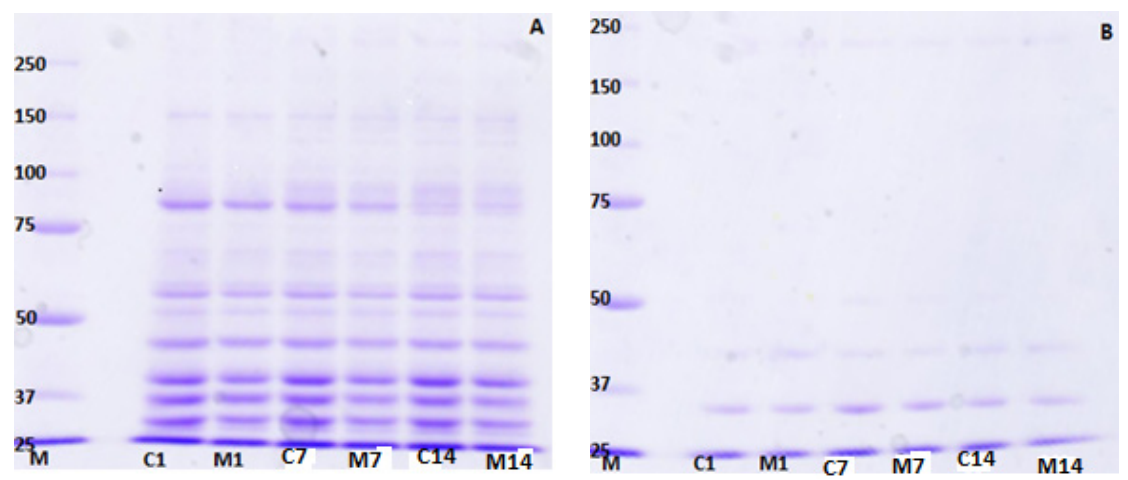

Figure 1. Sodium dodecyl sulfate-polyacrylamide gel electrophoresis profile of sarcoplasmic (A) and myofibrilar proteins (B) of duck breast meat ( $\mathrm{C}$, unmarinated; $\mathrm{M}$, marinated at 1,7 , and 14 days, respectively).

capacity. Wynveen et al. (2001) reported that the increased hydration capacity of marinade comes from the increased number of ions reacting with proteins in the case of phosphate and bicarbonate marinades.

Cooking loss and cooking yield are two important parameters with respect to commercial processing of meat products. These parameters are correlated with marinade absorption, as higher absorption leads to reduced cooking loss and increased cooking yield. Yoon (2002) observed a decrease in cooking losses for meat marinated with phosphates. Similarly, a decrease in cooking loss was also observed by Sen et al. (2005), who studied the impact of chilling and marination on broiler breast meat quality. Komoltri and Pakdeechanuan (2012) marinated Golek chicken and observed an increased cooking yield for marinated chicken compared to unmarinated chicken. Postmortem aging has non-significant effects on the

Table 7. Effect of aging and marination on texture profile analyses of duck breast meat

\begin{tabular}{|c|c|c|c|c|c|}
\hline & \multirow{2}{*}{ Treatments } & \multicolumn{3}{|c|}{ Aging period $(\mathrm{d})$} & \multirow{2}{*}{ SEM $^{1}$} \\
\hline & & 1 & 7 & 14 & \\
\hline \multirow[t]{3}{*}{ Hardness } & Control & 6.97 & 6.12 & 3.98 & 2.040 \\
\hline & Marinated & 6.35 & 5.70 & 3.62 & 2.222 \\
\hline & SEM $^{2}$ & 2.727 & 2.405 & 0.654 & - \\
\hline \multirow[t]{3}{*}{ Springiness } & Control & 0.85 & 0.84 & 0.84 & 0.009 \\
\hline & Marinated & 0.81 & 0.65 & 0.78 & 0.117 \\
\hline & $\mathrm{SEM}^{2}$ & 0.029 & 0.140 & 0.007 & - \\
\hline \multirow[t]{3}{*}{ Cohesiveness } & Control & 3.63 & 3.88 & 2.35 & 1.068 \\
\hline & Marinated & 3.38 & 2.41 & 2.21 & 0.998 \\
\hline & SEM $^{2}$ & 1.504 & 0.901 & 0.357 & - \\
\hline \multirow[t]{3}{*}{ Chewiness } & Control & 2.93 & 3.23 & 1.99 & 0.919 \\
\hline & Marinated & 2.82 & 1.56 & 1.84 & 0.751 \\
\hline & SEM $^{2}$ & 1.162 & 0.81 & 0.306 & - \\
\hline \multirow[t]{3}{*}{ Gumminess } & Control & 3.63 & 3.88 & 2.35 & 1.068 \\
\hline & Marinated & 3.38 & 2.41 & 2.21 & 0.998 \\
\hline & SEM $^{2}$ & 1.504 & 0.901 & 0.357 & - \\
\hline
\end{tabular}

SEM, standard error of the means.

${ }^{1} \mathrm{n}=9 .{ }^{2} \mathrm{n}=6$ )

${ }^{a-c}$ Different letters within the same column differ significantly $(p<0.05)$.

${ }^{A-C}$ Different letters within the same row differ significantly $(\mathrm{p}<0.05)$. cooking loss and yield of duck breast, and these findings affirm the previous results of Zhuang and Savage (2012), who reported similar results.

Duck breast meat is regarded as red meat, owing to its higher concentration of red muscle fibers. Higher amounts of fats (especially unsaturated fatty acids) and iron in red meat lead to increased instability and result in the production of higher TBARS values (Tang et al., 2001). Results of the current investigation indicate that the metalchelating effect of phosphates lowered TBARS production, confirming earlier results that marination has an antioxidant property (Ang and Young, 1989). Sanchez-Pena and Alvarado (2013) also observed a lower TBARS value for marinated chicken breast fillets compared to unmarinated samples. Blackhurst et al. (2011) observed a 20\% reduction in the formation of conjugated dienes during the cooking of red wine-marinated red meat. These results support that marination can be used as an active tool to enhance the lipid stability of meat and meat products.

High protein solubility is related to the increased waterholding capacity and cooking yield. Joo et al. (1999) correlated drip loss with protein solubility, and observed an increase in protein solubility and reduced drip losses with phosphate and bicarbonate marination. Protein solubility is also correlated with protein denaturation, as reduced protein solubility indicated a higher rate of protein denaturation (Choi et al., 2010). These findings have also shown harmony with the inferences of Huda et al. (2011) who investigated postmortem changes and protein denaturation in mule duck meat marinated with red wine. An increase in chicken breast protein solubility was observed after 7 to $8 \mathrm{~d}$ postmortem (Eady et al., 2014). Sodium chloride in marinade results in an increase in ionic strength and protein solubility, while phosphate increases the numbers of ions that react with protein and increase hydration (Sen et al., 2005). Similar findings were reported by Unal et al. (2006) that polyionic properties enable phosphates to attach to protein molecules on positive sites, leading to increased protein solubility and enhanced water binding. Aktas et al. 
(2003) demonstrated an increase in water-holding capacity, which was attributed to a rise in protein solubility and an increase in ions, as a result of salt marination.

The accumulation of low molecular weight proteins (30 $\mathrm{kDa}$ ) indicates postmortem proteolysis. Long-Li et al. (2012) stated that a $30 / 32-\mathrm{kDa}$ band in duck muscle was generated from the degradation of troponin-T. Chou et al. (1997) observed the proteolysis of duck breast for 14-daysaged samples, and reported that 0.1 and $0.2 \mathrm{M}$ lactic acid marination significantly accelerated protein degradation compared to unmarinated samples. The current result confirms that longer postmortem aging and marination will be helpful in protein degradation.

Findings of the present study regarding the texture analysis are in line with Komoltri and Pakdeechanuan (2012) who observed non-significant changes in springiness and cohesiveness between marinated and non-marinated Golek chicken. However, they observed a higher hardness for non-marinated chicken samples. The variation of hardness value among studies can be minimized by standardized method.

\section{CONCLUSION}

In conclusion, our results did not show that postmortem aging had significant effects on the marinade absorption, $\mathrm{pH}$, cooking loss, and yield of duck breast meat. However, postmortem aging was shown to significantly increase the color $\mathrm{a}^{*}$ and $\mathrm{b}^{*}$ values, TBARS values, and protein degradation. The marination of duck breast reduced cooking loss, improved cooking yield, reduced TBARS levels, and accelerated protein degradation. Total and myofibril protein solubility also increased with aging and marination. This study supports the use of postmortem aging for improvement of the physicochemical quality, and marination for improvement of cooking yield of duck breast meat. Therefore, the simultaneous use of aging and marination may be helpful for duck meat processing.

\section{CONFLICT OF INTEREST}

We certify that there is no conflict of interest with any financial organization regarding the material discussed in the manuscript.

\section{ACKNOWLEDGMENTS}

This research was supported by Golden Seed Project, Ministry of Agriculture, Food and Rural Affairs (MAFRA), Ministry of Oceans and Fisheries (MOF), Rural Development Administration (RDA), and Korea Forest Services (KFS) and Institute of Green Bio Science and Technology, Seoul National University.

\section{REFERENCES}

Aktas, N., M. I. Aksu, and M. Kaya. 2003. The effect of organic acid marination on tenderness, cooking loss and bound water content of beef. J. Muscle Foods 14:181-194.

Alvarado, C. Z. and A. R. Sams. 2004. Early postmortem injection and tumble marination effects on broiler breast meat tenderness. Poult. Sci. 83:1035-1038.

Ang, C. Y. W. and L. L. Young. 1989. Rapid headspace gas chromatographic method for assessment of oxidative stability of cooked chicken meat. J. Assoc. Off. Anal. Chem. 72:277281

Bauermeister, L. J. and S. R. Mckee. 2005. Utilizing marination and vacuum tumbling techniques to optimize tenderness of breast fillets deboned early postmortem. In: Proceedings of the XVII European Symposium on the Quality of Poultry Meat. Doorwerth, The Netherlands. pp. 23-26.

Blackhurst, D. M., R. D. Pietersen, F. H. O'Neill, and A. D. Marais. 2011. Marinating beef with South African red wine may protect against lipid peroxidation during cooking. Afr. J. Food Sci. 5:650-656.

Camou, J. P., J. A. Marchello, V. F. Thompson, S. W. Mares, and D. E. Goll. 2007. Effect of postmortem storage on activity of $\mu$ and m-calpain in five bovine muscles. J. Anim. Sci. 85:26702681.

Choi, Y. M., S. H. Lee, J. H. Choe, M. S. Rhee, S. K. Lee, S. T. Joo, and B. C. Kim. 2010. Protein solubility is related to myosin isoforms, muscle fiber types, meat quality traits, and postmortem protein changes in porcine longissimus dorsi muscle. Livest. Sci. 127:183-191.

Chou, R. G. R., T. F. Tseng, and M. T. Chen. 1997. Acceleration of post-mortem changes in Tsaiya duck (Anas platyrhynchos) breast muscle by lactic acid marination. Br. Poult. Sci. 38:7883.

Eady, M., D. Samuel, and B. Bowker. 2014. Effect of pH and postmortem aging on protein extraction from broiler breast muscle. Poult. Sci. 93:1825-1833.

Guerrero-Legarreta, I. and Y. H Hui. 2010. Handbook of Poultry Science and Technology. (Vol. 1) John Wiley \& Sons, Inc., Hoboken, NJ, USA.

Huda, N., A. A. Putra, and R. Ahmad. 2011. Proximate and physicochemical properties of Peking and Muscovy duck breasts and thighs for further processing. J. Food Agric. Environ. 9:82-88.

Joo, S. T., R. G. Kauffman, B. C. Kim, and G. B. Park. 1999. The relationship of sarcoplasmic and myofibrillar protein solubility to colour and water-holding capacity in porcine longissimus muscle. Meat Sci. 52:291-297.

Komoltri, P. and P. Pakdeechanuan. 2012. Effects of marinating ingredients on physicochemical, microstructural and sensory properties of Golek chicken. Int. Food Res. J. 19:1449-1455.

Laemmli, U. K. 1970. Cleavage of structural proteins during the assembly of the head of bacteriophage T4. Nature 227:680-685.

Lee, C. W., H. M. Choi, S. Y. Kim, J. R. Lee, H. J. Kim, C. Jo, and S. Jung. 2015. Influence of Perilla frutescens var. acuta water extract on the shelf life and physicochemical qualities of cooked beef patties. Korean J. Food Sci. An. 35:389-397.

Lemos, A. L. S. C., D. R. M. Nunes, and A. G. Viana. 1999. Optimization of the still-marinating process of chicken parts. 
Meat Sci. 52:227-234.

Lin, Y. C., W. T. Chen, and R. G. R. Chou. 2000. Postmortem changes in mule duck muscle marinated in red wine. J. Food Sci. 65:906-908.

Long-Li, T., N. J. Yen, and R. G. R. Chou. 2012. Changes in Muscovy duck breast marinated with ginger extract. Food Chem. 130:316-320.

Lorenzo, J. M., R. Bermudez, and D. Franco. 2013. Lipolysis, proteolysis and physic-chemical modifications during ripening of dry-cured duck breast. Eur. Food Res. Technol. 236:405-417.

Piao, M. Y., C. Jo, H. J. Kim, H. J. Lee, H. J. Kim, J. Y. Ko, and M. Baik. 2015. Comparison of carcass and sensory traits and free amino acid contents among quality grades in loin and rump of Korean cattle steer. Asian Australas. J. Anim. Sci. 28:16291640.

Sanchez-Pena, A. G. and C. Z. Alvarado. 2013. Marination and packaging impact on textural properties of home-frozen broiler breast fillets. Poult. Sci. 92:2404-2410.

Sen, R. A., B. M. Naveena, M. Muthukumar, Y. Babji, and T. R. K. Murthy. 2005. Effect of chilling, polyphosphate and bicarbonate on quality characteristics of broiler breast meat. Br. Poult. Sci. 46:451-456.

Smith, D. P. and J. C. Acton. 2010. Marination, cooking, and curing of poultry products. In: Poultry Meat Processing (Eds. C. M. Owens, C. Z. Alvarado, and A. R. Sams). CRC Press LLC, Boca Raton, FL, USA. pp. 311-336.

Smith, D. P., D. L. Fletcher, R. J. Buhr, and R. S. Beyer. 1993. Pekin ducklings and broiler chicken pectoralis muscle structure and composition. Poult. Sci. 72:202-208.
Tang, S., J. P. Kerry, D. Sheehan, D. J. Buckley, and P. A. Morrissey. 2001. Antioxidative effect of added tea catechins on susceptibility of cooked red meat, poultry and fish patties to lipid oxidation. Food Res. Int. 34:651-657.

Unal, B. S., F. Erdogdu, and H. I. Ekiz. 2006. Effect of temperature on phosphate diffusion in meats. J. Food Eng. 76: 119-127.

Wahlgren, N. M., C. E. Devine, and E. Tornberg. 1997. The influence of different $\mathrm{pH}$-courses during rigor development on beef tenderness. In: Proceedings of the 43rd International Congress of Meat Science and Technology, Auckland, New Zealand. pp. 622-623.

Wynveen, E. J., B. C. Bowker, A. L. Grant, J. M. Lamkey, K. J. Fennewald, L. Henson, and D. E. Gerrard. 2001. Pork quality is effected by early postmortem phosphate and bicarbonate injection. J. Food Sci. 66:886-891.

Yoon, K. S. 2002. Texture and microstructure properties of frozen chicken breast pretreated with salt and phosphate solutions. Poult. Sci. 81:1910-1915.

Young, L. L. and C. E. Lyon. 1997. Effect of calcium marination on biochemical and textural properties of pre-rigor chicken breast meat. Poult. Sci. 76:197-201.

Zhuang, H., B. Bowker, and D. Samuel. 2014. Effect of postmortem aging on marination performance of broiler breast pectoralis major categorized by color lightness. Poult. Sci. 93:3123-3129.

Zhuang, H. and E. M. Savage. 2012. Postmortem aging and freezing and thawing storage enhance ability of early deboned chicken pectoralis major muscle to hold added salt water. Poult. Sci. 91:1203-1209. 